\title{
Enzymes Activities in Two Sizes of Clarias. Gariepinus Exposed to on Farm Stress
}

\author{
Momoh M. $\mathbf{Y}^{1^{*}}$, Deekae S. $\mathbf{N}^{2}$, Abu, O.MG ${ }^{3}$ \\ Department of Fisheries and Aquatic Environment, Faculty of Agriculture, Rivers State University, Nkpolu- \\ Oroworukwo, Port Harcourt, Nigeria
}

*Corresponding Author: Momoh M. Y, Department of Fisheries and Aquatic Environment, Faculty of Agriculture, Rivers State University, Nkpolu-Oroworukwo, Port Harcourt, Nigeria

\begin{abstract}
The enzyme activities in the plasma of C. gariepinus juveniles and adults subjected to handling stress in the laboratory was carried out. Blood samples were collected from the fish and analyzed with standard methods. Results obtained indicate that Alkaline phosphatase (ALP) and Alanine transaminase (ALT), and Aspartate transaminase $(A S T)$ were significantly elevated $(P<0.05)$ in all the handling procedures under consideration. These alterations were more pronounced in the fish exposed to starvation and sorting. An indication that fish exposed to these handling activities were more stressed than fish in procedures.
\end{abstract}

Keywords: Catfish, Enzymes, Aquaculture, Stress, Immune system.

\section{INTRODUCTION}

The health issues have become a very important aspect of cultured animals, more importantly in farmed fish (Kestin et al.; 1995; Hastein, 2004). Stress in farmed fish is a very vital aspect to the health and productivity of fish because it affects their growth and can also lead to abnormal behaviour and depression in their immune system (Wedemeyer et al., 1996, Ashley, 2007). Wedemeyer et al. (1996) opined that environmental stress is inevitable in the life of fish, particularly those in intensive culture. Cultured fish are exposed to management practices that can lead to stress (Gabriel and Akinrotimi, 2011). Aquaculture operations such as handling, transportation or confinement have been reported to have some degrees of stress on fish (Akinrotimi et al., 2011). Some studies have been carried out to examine the response of fish to some stressors in aquaculture practices (Barton, 2000; Acerete et al., 2005). In nature, normally fish are exposed to natural things that can lead to stress but more stress are been caused to fish in artificial conditions such as aquaculture or in the laboratory. According to Davis et al., (2002), human activities is one factor that have led to an increased pollution of our natural water bodies and is one category of things that causes stress in the environment. Fishes respond to this stress with all levels of organization (Hur et al.; 2007), from the cells to the individual organism (Barton and Iwama, 1991) and also extend to the general population (Barton, 2002).

Enzymes are biochemical macromolecules that control the metabolic process of organisms, thus a slight variation in enzyme activities would affect the organism metabolic integrity (Roy, 2002). They are indispensable for signal transduction and cell regulation, often via kinases and phosphates. The activities of alkaline phosphatase, alanine aminotransferase, aspartate and aminotransferase, are useful marker enzymes of damage to the system of the fish (Akanji et al., 1993; Akinrotimi et al., 2013). Maintenance of internal homeostasis through biochemical processes in the Kreb's cycle may be reflected by variation in the levels of the enzymes AST, ALT, ALP in the plasma of the fish, triggered by cellular damage in the functional organs such as liver, heart, gill, muscles and kidney as they are generally found in the tissues of these organs (Gabriel et al., 2010). Both serum AST and ALT activities in the cell of an organism are raised when infections affects cell integrity (Gabriel and George, 2005).

Moreover, evaluation of blood biochemistry was considered as a useful tool for the diagnosis of diseases and assessing the physiological status of fish (Gabriel et al., 2011). This is because stress response in fish is characterized by biochemical and physiological changes which may be manifested in changes induced by culture systems (Tiwari and Singh, 2004; Akinrotimi et al., 2012). The disruption of the biochemical and physiological integrity is assessable by the changes in the enzyme activities in 
plasma of the fish (Van Der Oost et al., 2003). Hence, the present study was carried out to evaluate the effects of different handling aquaculture procedures on the plasma enzymes of African Catfish $C$. gariepinus which is widely cultured in different parts of Nigeria.

\section{MATERIALS AND MethodS}

\subsection{Experimental Process}

This study was carried out at the African Regional Aquaculture Centre (ARAC) Aluu, Port Harcourt, Rivers State. A total of 120 C.gariepinus comprising 60 adult size (mean total length $32.81 \mathrm{~cm} \pm$ 3.01SD; mean weight $972.42 \mathrm{~g} \pm 30.01 \mathrm{SD}$ ) and 60 juvenile size (mean length $15.02 \pm 4.77$; mean weight 309.01 \pm 11.44 ) were procured from African Regional Aquaculture Centre (ARAC) Aluu, Port Harcourt, Rivers State, Nigeria. They were held in circular plastic aquaria in the hatchery unit before they were been subjected to the selected on-farm-procedures (treatments). All the experimental procedures were carried out in the hatchery unit the same day.

The fish were subjected to some common selected handling procedures in aquaculture that result in stress in fish, namely: Sorting; Overcrowding; Starvation. Blood samples were collected from the kidney of the C.gariepinus by puncturing it using a hypodermic needle. Blood samples were collected from three fish at rest state before and after exposure to these on-farm stresses.

\subsection{Determination of Alkaline Phosphatase (ALP)}

The concentration of alkaline phosphatase in plasma was determined spectrophotometrically using RANDOX diagnostic kit on RX Monza analyzer made by Randox laboratories limited, United Kingdom (model RX MONZA AP 542). This method was carried out according to Rec et al., (1972) and Englehardt, (1970). Three cuvettes marked Macro, Semi micro and Micro was arranged in a rack. $0.05 \mathrm{ml}$ of plasma sample was pipetted into Macro cuvette, $0.02 \mathrm{ml}$ sample was pipetted into semi-micro and $0.01 \mathrm{ml}$ sample was pipetted into micro cuvette. $3.00 \mathrm{ml}$ reagents were pipetted into macro cuvette, $1.00 \mathrm{ml}$ of the reagents were pipetted into semi-micro cuvette and $0.50 \mathrm{ml}$ of the reagents was pipetted into the micro cuvette. The solution was mixed and the initial absorbance was read at $\mathrm{Hg} 405 \mathrm{~nm}$ at a temperature of $37^{\circ} \mathrm{C}$. It was read again after 1,2 , and 3 minutes. (Timer was set to run simultaneously).

ALP concentration was calculated using the following formular:

$\mathrm{U} / \mathrm{l}=\underline{2760 \times \text { Absorbance } 405 \mathrm{~nm}}$

Minute

\subsection{Determination of Aspartate Aminotransferase (AST)}

The concentration of Aspartate aminotransferase in plasma was determined spectrophotometrically using RANDOX diagnostic kit on RX Monza analyzer made by Randox laboratories limited, United Kingdom (Model RX MONZA AS 101). This method was carried out according to Reitman et al., (1975) and Schmidt et al., (1963). AST was measured by monitoring the concentration of Oxaloacetate hydrazone formed with 2,4dinitrophenylhydrazine.

Two test tubes were labeled blank (B) and sample (S). In the reagent blank test tube was pipetted $0.5 \mathrm{ml}$ of buffer (reagent 1) followed by $0.1 \mathrm{ml}$ distilled water, while the sample test tube labeled (S) was pipetted $0.1 \mathrm{ml}$ plasma sample and $0.5 \mathrm{ml}$ of buffer. The mixture was incubated for exactly 30 minutes at $37^{\circ} \mathrm{C}$. Later $0.5 \mathrm{ml}$ of 2,4-dinitrophenylhydrazine (reagent 2) was pipetted into the two test tubes, mixed and allowed to stand for exactly 20 minutes at $25^{\circ} \mathrm{C}$. Later, $5.0 \mathrm{ml}$ of Sodium hydroxide was pipetted into the two test tubes. The solution was mixed and the absorbence of the sample was read at $546 \mathrm{~nm}$ against the reagent blank after 5 minutes. The activity was extrapolated from the standard curve.

\subsection{Determination of Alanine Aminotransferase (ALT)}

Alanine amino transferase was measured spectrophotometrically using Randox diagnostic kit (Model AL100) according to the method of Reitman et al., (1957) and Schmidt et al., (1963). This was done by monitoring the concentration of Pyruvate hydrazone formed with 2,4 dinitrophenylhydrazine. Two test tubes were labeled Reagent blank (B) and Sample (S). $0.5 \mathrm{ml}$ of $100 \mathrm{mmol} / \mathrm{l}$ phosphate buffers and 0.5 $\mathrm{ml}$ of $200 \mathrm{mmol}$ of L-alanine and $0.1 \mathrm{ml}$ of distilled water was pipetted into reagent blank test tube. 0.1 $\mathrm{ml}$ of plasma sample, $0.5 \mathrm{ml}$ of $100 \mathrm{mmol} / \mathrm{l}$ phosphate buffers and $0.5 \mathrm{ml}$ of $200 \mathrm{mmol}$ of L-alanine was pipetted into test tube (S). The solution in the three tubes was mixed, incubated for exactly 30 minutes at $370 \mathrm{C}$. Later, $0.5 \mathrm{ml}$ of $2.0 \mathrm{mmol} / 1$ 2,4-dinitrophenylhydrazine was pipetted into reagent blank tube and sample test tubes. The solution was mixed, incubated for exactly 20 minutes at $250 \mathrm{C}$. Lastly, $5.0 \mathrm{ml}$ of Sodium hydroxide was pipetted into reagent test tube and sample test tube. The solution was mixed and 
the sample absorbance was read at $578 \mathrm{~nm}$ against the reagent after 5 minutes. The activity was extrapolated from the standard curve.

\subsection{Statistical Analysis}

The data were collated and analyzed using one-way analysis of variance, (ANOVA) at 5\% level of significance. Post-hoc comparison of significance of variance results gotten from ANOVA was done using DMRT (Duncan Multiple Range Test) tests. These analyses were carried out based on a computer programme SPSS 10.0 .

\section{RESULTS}

The enzyme activities in the plasma of $C$. gariepinus juveniles exposed to different on farm procedures is presented in Table 1. The highest enzyme activities were observed in fish exposed to sorting, and closely followed by the one exposed to starvation. However, AST and ALT were within the same range in overcrowding and control values. The values of ALP, ALT and AST in adult sizes of C.gariepinus subjected to handling stress were elevated in all the farming procedures compared to the control values with the highest values of $488.02 \pm 42.02,32.02 \pm 1.33$ and 59.66 $\pm 6.51 \mathrm{U} / \mathrm{l}$ for ALP, ALT and AST respectively (Table 2).

Table1. Enzymes in Plasma Juvenile Sizes of C. gariepinus Exposed to Some Handling Procedures (Mean \pm SD)

\begin{tabular}{|l|l|l|c|}
\cline { 2 - 4 } & \multicolumn{3}{|c|}{ Enzymes (U/I) } \\
\cline { 2 - 4 } & ALP & \multicolumn{1}{|c|}{ ALT } & AST \\
\hline Control & $238.89 \pm 34.42^{\mathrm{a}}$ & $11.33 \pm 2.08^{\mathrm{a}}$ & $23.33 \pm 2.08^{\mathrm{a}}$ \\
\hline Starvation & $400.64 \pm 31.48^{\mathrm{c}}$ & $13.33 \pm 1.34^{\mathrm{a}}$ & $43.33 \pm 4.04^{\mathrm{b}}$ \\
\hline Overcrowding & $383.40 \pm 45.60^{\mathrm{b}}$ & $15.09 \pm 1.34^{\mathrm{a}}$ & $32.66 \pm 4.04^{\mathrm{b}}$ \\
\hline Sorting & $409.40 \pm 45.60^{\mathrm{c}}$ & $25.89 \pm 1.09^{\mathrm{b}}$ & $43.66 \pm 4.61^{\mathrm{b}}$ \\
\hline
\end{tabular}

Means within the Same Column with Different Superscripts Are Significantly Different $(P>0.05)$

Table2: Enzymes in Plasma Adult Sizes of C. gariepinus Exposed to Some Handling Procedures (Mean $\pm S D$ )

\begin{tabular}{|l|l|l|l|}
\cline { 2 - 4 } & \multicolumn{3}{|c|}{ Enzymes (U/I) } \\
\cline { 2 - 4 } & \multicolumn{1}{|c|}{ ALP } & ALT & AST \\
\hline Control & $308.77 \pm 41.092^{\mathrm{a}}$ & $14.02 \pm 2.018^{\mathrm{a}}$ & $28.92 \pm 2.21^{\mathrm{a}}$ \\
\hline Starvation & $456.91 \pm 30.32^{\mathrm{b}}$ & $16.44 \pm 1.37^{\mathrm{a}}$ & $53.77 \pm 3.79^{\mathrm{b}}$ \\
\hline Overcrowding & $403.21 \pm 33.01^{\mathrm{b}}$ & $18.88 \pm 1.92^{\mathrm{a}}$ & $42.66 \pm 5.67^{\mathrm{b}}$ \\
\hline Sorting & $488.02 \pm 42.02^{\mathrm{c}}$ & $32.02 \pm 1.33^{\mathrm{b}}$ & $59.66 \pm 6.51^{\mathrm{b}}$ \\
\hline
\end{tabular}

Means within the Same Column with Different Superscripts Are Significantly Different $(P>0.05)$

\section{DisCuSSION}

In this study, the enzymes under consideration are very vital and are useful biomarker that reveals intricate cellular damage long before revealing the structural damage by some standard techniques (Mgbenka et al., 2005). The activities of the enzymes (alkaline phosphatase, alanine aminotransferase, aspartate and aminotransferase), considered in this study, are useful marker in revealing damaged liver and kidney (Akanji et al., 1993). These biochemical changes try to maintain equilibrium in the presence of stress. A shift in the activities of enzymes from the control is also used as a relevant stress indicator. A major biochemical response to the effect of stress in fishes is the elevation of a number of enzymes (Akinrotimi et al., 2007). In this study exposure of $C$. gariepinus to different on farm procedures generally resulted in elevation of these enzymes when compared to the control values. In this study AST activity was elevated in the muscles probably to enable the fish cope with the energy demand during stress condition. Similar findings, suggest that this energy demand could be satisfied through amino acid. ALP activity and ALT increased in the plasma of exposed fish. Alanine transaminase (ALT, Aspartate transaminase (AST) and Alkaline phosphate (ALP) are important enzymes giving indication for liver function through controlling transferring amino group function of alpha amino acids to alpha keto acids. Large amount of ALT and AST are released into animal blood, mostly during liver cell damage (Thomas et al., 1999).

Moreover, stressful aquaculture practices have been reported to affect enzyme profiles in fish (Akinrotimi et al., 2012). Nte et al. (2018) observed that increase in ALT, ALP and AST activities in 
fish stressed by low DO and high stocking density. They reported that elevation of tese enzymes may reflect the use of excess hydrocarbons from amino acids to supply energetic demands. The rise in ALT and AST in stressed fish may indicate use of dietary amino-acids for growth as well as compensatory for energy demand as a response to the stressor. These enzymes have no other known functions in the serum other than to provide information about hepatic state and disorders. These disorders could be as a result of injury or liver disease. The injury could be caused by reactive metabolites, resulting from xenobiotic metabolism in the liver (Akinrotimi et al., 2018). Also, the observed elevated levels of ALP may indicate an increase in the rate of phosphorylation and transport of molecules across the cell membrane, which may result to increased detoxification effects of the kidney and thus a possible stress on the kidney membrane that could cause cell injury (Luskova et al., 2002). The increases could also result in a shift in biosynthesis, mixed-function oxidase and energy metabolism pathways (George et al., 2017).

\section{CONCLUSION}

This study revealed that common on-farm procedures such as the ones studied in this study can lead to stress in fishes as a whole as evident in the elevation of these enzymes. Hence, this should be minimized as much as possible to reduce the effect of these procedures on the fish and this can be achieved through a better farm management practises.

\section{REFERENCES}

[1] Acerete, L; Balasch, J. C; Espinosa,E; Josa, A and Tort, L. (2005). Physiological responses in Eurasian perch (Perca fluviatilis, L.) subjected to stress by transport and handling. Aquaculture 237, 167-178.

[2] Adams, S. M (1990). Status and use of biological indicators for evaluating the effects of stress on fish, American Fisheries Society Symposium, 8,1.

[3] Akanji MA, Olagoke OA and Oloyede OB. 1993. Effect of Chronic consumption of metabisulphate on the integrity of the rat kidney cellular system. Fish Toxicol, 81: $173-179$.

[4] Akinrotimi O.A., Edun, O.M, and Ukwe,O.I.K (2018).Effects of Anaesthetics on Metabolic Enzyme Activities in African Catfish, Clarias gariepinus (Burchell, 1822) Journal of FisheriesSciences.com 12(1): 022-028.

[5] Akinrotimi, O.A., Opara, J.Y., \& Ibemere I.F. (2011). Effects of handling stress on immune functions of Black jaw tilapia, Sarotherodon melanotheron. Nigerian Journal of Fisheries, 8(1),154-158.

[6] Akinrotimi, O.A., Gabriel, U.U., \& Ariweriokuma, S.V. (2012). Haematotoxicity of cypermethrin to African catfish Clarias gariepinus under laboratory conditions. Journal of Environmental Engineering and Technology, 1(2), 20-25.

[7] Akinrotimi, O.A., Gabriel, U.U., \& Orokotan, O.O. (2013). Changes in Enzymes activities of Clarias gariepinus brood fish exposed to anaesthtics metomidate. Applied Ecology and Environmental Science, 1(3), $37-40$.

[8] Akinrotimi, O. A., Abu, O. M. G; Ansa, E. J; Edun, O. M and George, O. S (2009). Haematological responses of Tilapia guineensis to acute stress. International Journal of Natural and Applied Sciences. (5 (47): 338-343.

[9] Akinrotimi, O. A; Ansa, E. J, Owohonda, K. N; Onunkwo, D. N; Edun, O. M; $\quad$ Anyanwu, P. E; Opara, J. Y and Cliffe, P. T. (2007). Effects of transportation stress on haematological parameters of blackchin Tilapia, Sarotherodon melanotheron. J. Animal Vet. Serv. Adv. 6 (7): 84-85.

[10] Ashley, C. I. (2007). Stress in Farmed Fish and their effect. Aquic Inter 7, 101-115.

[11] Barton, B. A and Iwama, G. K. (1991). Physiological changes in fish from stress in aquaculture with emphasis on the responses and effects of corticosteroids. Annual Review of Fish Diseases 1:3-26.

[12] Barton, B. A. (2000). Salmonid fishes differ in their cortisol and glucose responses to handling and transport stress. N Am J Aquaculture 62: 12-18.

[13] Barton, B. A. (2002). Stress in fishes: a diversity of responses with particular circulating corticosteroids. Integ and Comp Biol 42, 517-525.

[14] Davis, R. B; Griffin, B. R; Gray, W. L. (2002). Effect of handling stress on susceptibility of channel catfish Ictalurus punctatus to Ichthyophthirus multifilis and channel virus infection. Aquaculture 214:55-66.

[15] Gabriel UU and George ADI (2005). Plasma enzymes in Clarias gariepinus exposed to chronic levels of Round up. Environ Ecol, 23(2): 271-276.

[16] Gabriel UU, Obomanu FG and Edori OS. 2010. Biochemical changes in hybrid cat fish (Heterobranchus bidorsalis, Clarias gariepinus) treated with Nuracron. Chinese J Appl Environ Biol, 16(3): 353-357. 
[17] Gabriel, U.U., \& Akinrotimi, O.A. (2011). Management of Stress in fish for sustainable aquaculture development. Research, 3(4), $28-38$.

[18] Gabriel, U.U., Uedeme-Naa, B., \& Akinrotimi, O.A. (2011). Pollutant induced altered behaviours in fish: A review of selected literature. Journal of Technology and Education in Nigeria (JOTEN), 16(1), 9-23.

[19] George, A.D.I., Akinrotimi O.A.\& Nwokoma,U. K. (2017). Haematological Changes in African Catfish (Clarias gariepinus) Exposed To Atrazine and Metolachlor in the Laboratory. Journal of Fisheries Science.com. 11 (3), 48-54.

[20] Hastein, T. (2004). Animal welfare issues relating to aquaculture, OIE Global Conference on Animal Welfare, Paris, France, Pp 219-227.

[21] Hur, J. W, Park, I. S and Chang, Y. J. (2007). Physiological response of the olive flounder, Paralichthys olivaceus, to a series stress during the transportation process, Ichtyol. Res. 54, 32-37.

[22] Kestin, S; Wotton, S and Adams, S. (1995). The effect of $\mathrm{CO}_{2}$, concussion of electrical stunning of rainbow trout (Oncorhynchus mykiss) on fish welfare. In: European Aquaculture Society (eds) Quality in Aquaculture.Special Publication 23. Gent, Belgium, 380-381.

[23] Luskova V, Svoboda M and Kolarova J. 2002. The effects of diazinon on blood plasma biochemistry in carp (Cyprinus carpio). Arch Vert Med,71:117-125.

[24] Mgbenka BO, Oluah NS and Arungwa AA. 2005. Erythropioetic response and haematological parameters in the cat fish Clarias alpopunctatus exposed to sublethal concentrations of actellic. Ecotoxicol Environ Saf, 62:436- 440 .

[25] Nte, M.E., Edun, O.M and Akinrotimi O.A. (2018). Biochemical Changes in Mudskipper (Periophthalmuspapilio) exposed to sodium bromide. International Journal of Advanced Research in Medical \& Pharmaceutical Sciences (IJARMPS-ISSN-2455-6998) 3(2)1-6.

[26] Ogueji EO and Auta J. 2007. Investigation of biochemical effects of acute concentrations of lambdacyhalothrin on African catfish Clarias gariepinus- Teugels. J Fisheries International, 2(1): 86-90.

[27] Roy SS. 2002. Some toxicological aspect of chlorpyrifors to the intertidal fish Boleophthaimus dussumieri. Ph.D Thesis, University of Mumbai, India. $52-71$.

[28] Thomas, P. M; Pankhurst,N. W and Bremner, H. A. (1999). The effect of stress and exercise on postmortem biochemistry of Atlantic salmon and rainbow trout. J Fish Biol 54, 1177-1196.

[29] Tiwari S and Singh A. 2004. Piscicidal activity of alcoholic extract of Nerium indicum leaf and their biochemical stress response on fish metabolism. Afr J Trad, 1:15-29.

[30] Van der Oost R, Beyer J and Vermeulen NP. 2003. Fish bioaccumulation and biomarkers in environmental risk assessment: a review. Environ Toxicol Ph, 13: 57-149.

[31] Wall, A. J (2001). Ethical considerations in the handling and slaughter of farmed fish. In: Kestin S, Warriss PD (eds). Farmed fish quality. Blackwell Science. Bristol, England, Pp 108-119.

[32] Wedemeyer, G. A; Barton, B. A, Mcleay, D. J and Herbert, H. (1996). Fish and stress. American Fisheries Society, Bethesda. 235-243.

Citation: Momoh M. Y, et.al, "Enzymes Activities in Two Sizes of Clarias. Gariepinus Exposed to on Farm Stress”. International Journal of Innovative Studies in Aquatic Biology and Fisheries, 5(3), pp.16-20. http://dx.doi.org/10.20431/2454-7670.0503003

Copyright: () 2019 Authors. This is an open-access article distributed under the terms of the Creative Commons Attribution License, which permits unrestricted use, distribution, and reproduction in any medium, provided the original author and source are credited. 